\title{
Some Middle Jurassic dinocysts from the Brent Group of the northern North Sea
}

\author{
DAVID A. BAILEY ${ }^{1}$ and MARK PARTINGTON ${ }^{2}$ \\ 1. BioStrat Ltd., Glenanan, Brough Hill, Wigton, Cumbria CA7 8PF. UK. \\ 2. BP Exploration, 301 St. Vincent Street, Glasgow G2 5DD, Scotland.
}

\begin{abstract}
Selected dinocyst taxa from the Brent Group equivalent (Bathonian-Aalenian) of the northern North Sea are described. The diagnosis of Dissiliodinium (Drugg 1978) is emended. Two new species: Dissiliodinium willei and Durotrigia aspera are introduced. In addition, several new taxa are informally described and illustrated.
\end{abstract}

\section{INTRODUCTION}

This paper describes some initial results of palynological analysis of conventional core samples from the Brent Group (Aalenian-Bathonian) and lower Humber Group (BathonianEarly Callovian). All material is from wells in blocks $9 / 8$ a and $9 / 9 \mathrm{~b}$ in the UK Sector of the northern North Sea (Fig.1). Several hundred samples have been analysed and many previously undescribed marine species were recorded. Selected dinocyst taxa are described in the following systematic section. All of these forms have stratigraphic potential.

All type and illustrated material are housed in the collection of BP Exploration Ltd, 301 St. Vincent Street, Glasgow, Scotland.

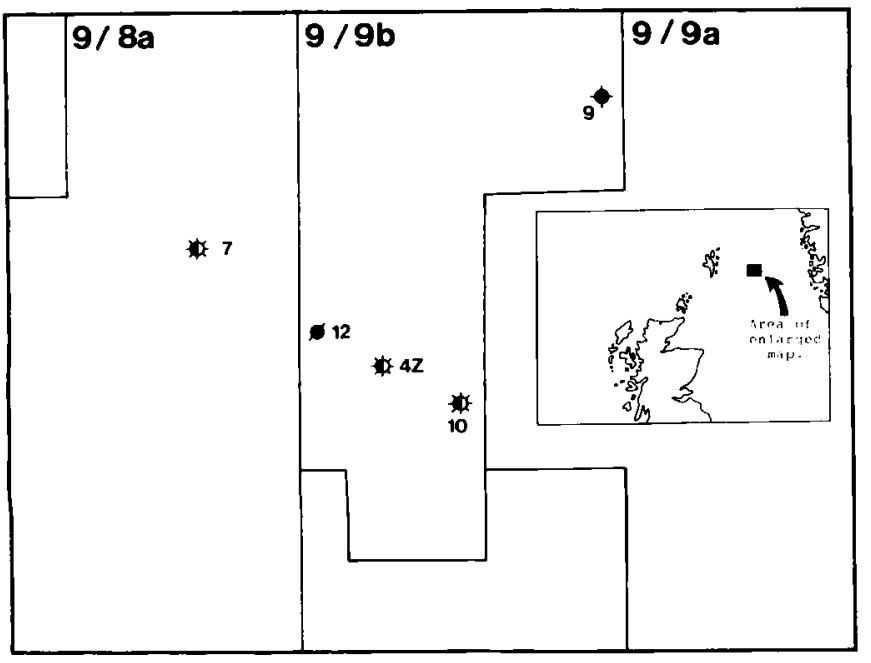

Fig. $1 \quad$ Location map of study wells

\section{SYSTEMATIC PALYNOLOGY}

Division Pyrrophyta Pascher 1914

Class Dinophyceae Fritsch 1935

Order Peridiniales Haeckel 1894

Genus Crussolia Wolfard \& Van Erve 1981, emend. Smelror \& Aarhus 1989.

Type species. Crussolia deflandre $i$ Wolfard and Van Erve 1981. Remarks. Smelror and Aarhus (1989) emended the diagnosis of Crussolia to incorporate the morphological features of their new species $C$. dalei, which is a tabulate variety. This is slightly contentious, because many genera are currently separated on the basis of the presence or absence of tabulation (e.g.) Spiniferites vs. Achomosphaera, Lagenadinium vs. Stephenelytron, Pareodinia vs. Paragonyaulacysta and Dissiliodinium vs. Durotrigia). If this precedent were to be followed, then a new genus, incorporating cavate pareodinioid dinocysts with reflected tabulation, would have to be erected.

We agree with Smelror and Aarhus (op. cit.) that Crussolia never has a $5 \mathrm{I}$ archaeopyle as indicated in the original diagnosis of Wolfard and Van Erve (1981). We would, however, interpret the true archaeopyle structure as variable intercalary (type I-3I) rather than type $3 \mathrm{I}$.

Crussolia perireticulata Aarhus et al., 1989

(PI.3, Figs. 4, 5, $7 \& 8$ )

1989 Crussolia sp. Smelror and Aarhus, p.44, Figs.5C, D.

1989 Crussolia perireticulata Aarhus et al., p.46, Figs 5a-i.

Description. Proximate pareodinioid dinocyst with a pyriform outline and of intermediate to large size (60-100 micrometers). Cysts circumcavate with thicker, scabrate endophragm and thinner, smoother periphragm. The periphragm is modified into an imperfect reticulum that may be perforate or vacuolate. There are generally no indications of tabulation other than the 
archaeopyle. Some specimens have a larger, more regular reticulate ornament along the cingulum.

Occurrence. This species has been observed in sediments of Bathonian to Middle Oxfordian age. There is some doubt as to whether the younger records are in situ or reworked, because it is rare and inconsistent in the Oxfordian and Callovian. $C$. perireticulata has also been recorded from Callovian sediments of the Norwegian Sector of the North Sea (Aarhus et al. 1989) and from Late Bathonian to Callovian aged sediments of Kong Karls Land and Franz Josef Land (Smelror and Aarhus, 1989). There are no published records of this species from onshore UK.

Genus Dissiliodinium Drugg 1978 emend.

Type species. Dissiliodinium globulum Drugg 1978, p.68, pl.4, figs 4-6.

Emended diagnosis. Proximate subspherical gonyaulacoid dinocyst of intermediate to large size (50-110 micrometers). The autophragm is smooth, or more normally ornamented by nontabular features of low relief. The archaeopyle is variable precingular (type 1P-5P), opercular pieces normally free. Apical plates and plate 6" remain attached to hypocyst. Epicystal tabulation derived from the outline of archaeopyle indicate formula; 4', 0a, 6". Faint parasutures delineating the cingulum may rarely be observed. Hypocyst lacks any indication of tabulation.

Remarks. Dissiliodinium is originally described with a type 4P-5P archaeopyle. The generic diagnosis is emended to include the variable IP-5P archaeopyle and the absence of dorsal intercalary plates on the epicyst.

Comparison. Dissiliodinium differs from Durotrigia Bailey (1987) in being non-tabulate and lacking dorsal intercalary plates on the epicyst.

\section{Dissiliodinium willei sp. nov.}

(Pl.1, figs 1-4, text-fig.2).

Derivation of name. This species is named after Herr Wolfgang Wille, Research Fellow at the Centre for Palynological Studies, University of Sheffield, England.

Diagnosis. Subspherical to ellipsoidal proximate gonyaulacoid dinocyst. Autophragm variously ornamented with low relief granulate, vermiculate and reticulate sculpture. Tabulation absent, indicated by archaeopyle only (type 1P-5P). Average size $75 \times 60$ micrometers (holotype $81 \times 63$ micrometers).

Holotype. Slide B.7058.4, England Finder ref. K53/3.

Type locality. UKCS Well $9 / 9 \mathrm{~b}-10$ at $3550.70 \mathrm{~m}$ (conventional core).

Description. The cyst outline is often modified by one or two strong, sub-parallel folds. The autophragm is ornamented by low relief features which vary in complexity, from isolated low mounds or granules, to more elongate and branching vermiculae, which may develop into an incomplete reticulum. This variation in ornament is often seen on a single specimen. Tabulation is generally indicated by the archaeopyle only, but in some rare forms with stronger ornament, individual elements may merge to form partial cingular parasutures. The archaeopyle is formed by the loss of up to five precingular plates. Size intermediate, generally around 70 micrometers in length and 50 micrometers width.

Comparison. Dissiliodinium willei sp.nov. is distinguished from other species of the genus by the style of ornament. The low undulose vermiculae and reticulate areas are coarser and distributed in a more open pattern than in D. globulum (Drugg 1978).

Occurrence. This species has been observed in sediments ranging in age from Early Bajocian to Callovian. It is often seen in flood abundance in early Middle Jurassic semi-marine sediments from the North Sea and adjacent areas. It appears however, to be a rare form in southern England (pers. obs).

Genus Durotrigia Bailey 1987

Type species. Durotrigia daveyi Bailey 1987, p.89.

Durotrigia aspera sp. nov.

(PI.2, figs 1-6, 9, text-fig.3).

Derivation of name. Latin asper: rough. With reference to the coarse intratabular ornament.

Diagnosis. A species of Durotrigia with full gonyaulacoid tabulation reflected by irregular, undulose ridges and low crests, which often develop proximal vacuoles. The autophragm is relatively thick and intratabular areas are coarsely granulate, vermiculate or semi-reticulate. The archaeopyle is variable precingular, type $1 \mathrm{P}-5 \mathrm{P}$. Average size c. $70 \times 55$ micrometers (holotype 62 448 micrometers).

Holotype. Slide C.0187.1 England Finder ref. S49/4.

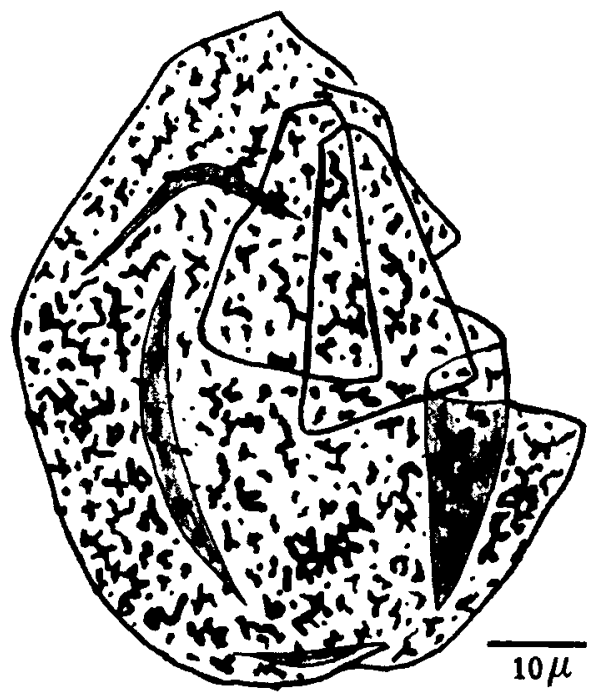

Fig.2 Dissiliodinium willei sp. nov. Holotype 

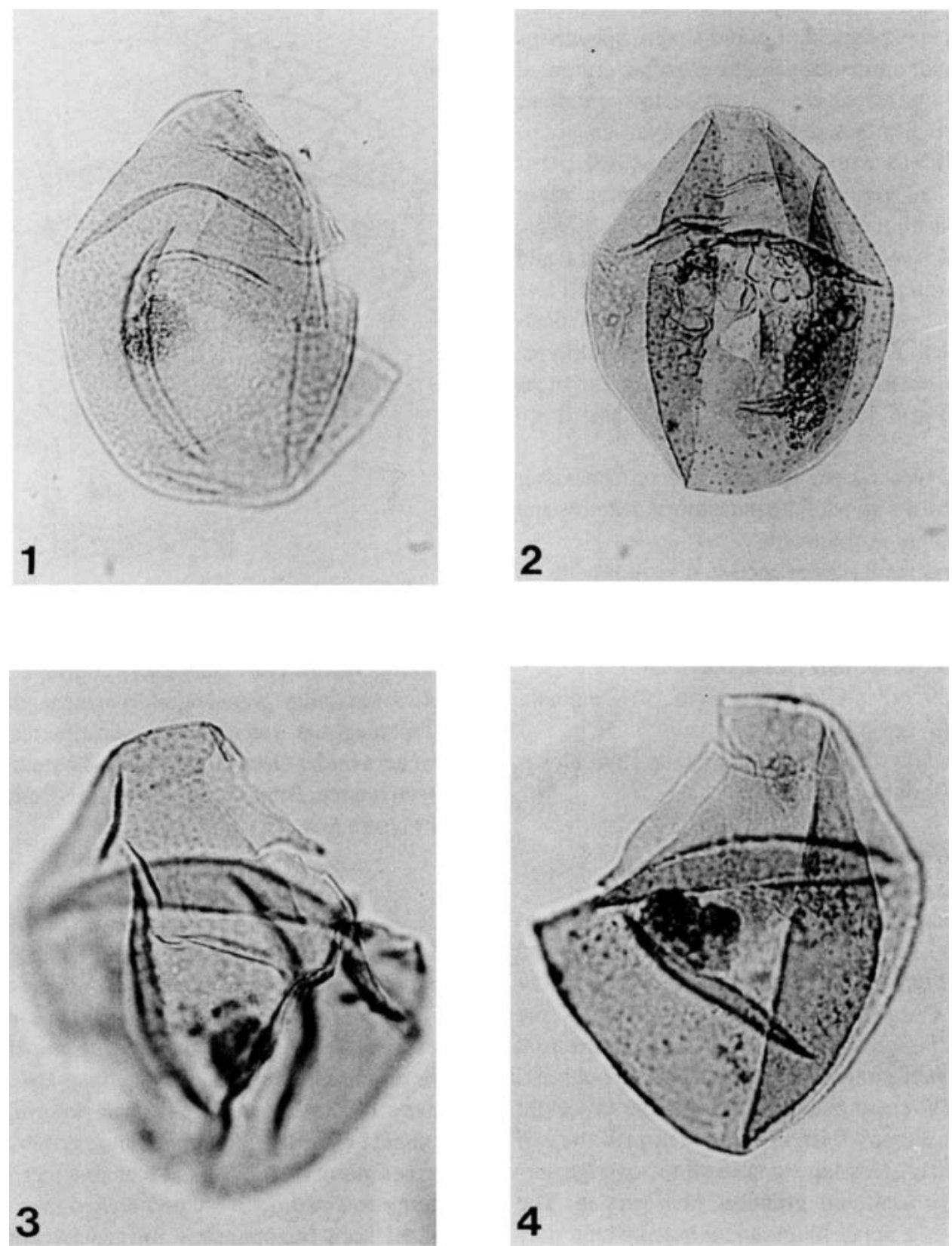

\section{Explanation Of Plate 1}

Dissiliodinium willei sp. nov., all x800 approx.

Fig.1. Holotype. Note the two precincular opercula trapped within the epicyst. UKCS Well 9/9b-10, 3550.7m (slide B.7058.4) EF K53/3. Fig. 2. This specimen shows granulate rather than vermiculate ornament. The archaeopyle has not operated, though incipient sutures are visible on the epicyst. Note the characteristic longitudinal folds. UKCS Well 9/9b-10, 3550.7m (slide 4), EF K44/1

Fig. 3. Lateral view of specimen with $2 \mathrm{P}$ archaeopyle and strongly vermiculate ornament. UKCS Well 9/9b-10,3550.7m (slide 4), EF H44/3.

Fig. 4. Lateral view of specimen with complete or partial loss of 4 precingular plates. UKCS Well 9/9B-10, 3550.7m (slide 4), EF K51/1. 
Type locality. UKCS Well 9/9b-4Z at 12314'.

Description. This species is of intermediate size $(70-90 \mathrm{mi}-$ crometers) and has a subspherical or ovoid shape. Specimens with several precingular operculae missing are often crumpled and shapeless. Parasutural features comprise low undulose ridges or crests, which often develop proximal vacuoles. Intratabular areas exhibit a coarse ornamentation of isolated or coalescing granules and vermiculae. The para sutural ridges reflect a gonyaulacoid tabulation $\left(4^{\prime}, 2 \mathrm{a}, 66^{\prime \prime}, 6 \mathrm{c}, 6^{\prime \prime}, 1 \mathrm{p}, 1\right.$ "'”, $^{\circ}, 5 \mathrm{~s}$, fpa). The autophragm is relatively thick (1-2 micrometers) and the archaeopyle is formed by the loss of between one and five precingular plates. Excystment begins dorsally at the 3" position and progresses ventrally in both directions. In the holotype, only one precingular operculum has fully operated, but cysts with variable dehiscence; $1 \mathrm{P}, 2 \mathrm{P}, 3 \mathrm{P}, 4 \mathrm{P}$ and $5 \mathrm{P}$ have been recorded.

Comparison: Durotrigia aspera sp. nov. differs from other species of the genus by the style of the parasutural features and the very coarse intratabular ornament.

Occurrence. This species has been recorded in sediments of Bathonian age, where it can be common or abundant.

Genus Gonyaulacysta Deflandre 1964, emend. Sarjeant 1969, emend. Stover \& Evitt 1978, emend. Sarjeant 1982.

Type species. Gonyaulacystajurassica (Deflandre 1938. Norris \& Sarjeant 1965, emend. Sarjeant 1982.

Gonyaulacysta sp. 1.

(Pl.3, figs.3, 6, 9, text-fig.3)

Description. Subspherical proximate dinocyst of small to intermediate size (50-70 microns). Cysts suturocavate and epicornucavate, with thicker endophragm and thinner, more delicate periphragm. Gonyaulacoid tabulation formula $\left(4^{\prime}, 0 \mathrm{a}\right.$, 6", 6c, 6"”, 1p, 1"”, ?s, fpa) reflected by distinct parasutural crests (formed by the periphragm only) which are perforate and distally denticulate. The crests average 5 micrometers in height and have a tent-like structure, formed by separation of the two wall layers. Intratabular areas have a smooth to scabrate surface, with irregularly scattered granules or verrucae. The periphragm also forms a small blunt apical horn, which may also be perforate. The archaeopyle is precingular, type P (3" only).

Remarks. Gonyaulacysta sp.1. differs from $G$. pectinigera (Gocht) Fensome 1979 in having perforate, rather than

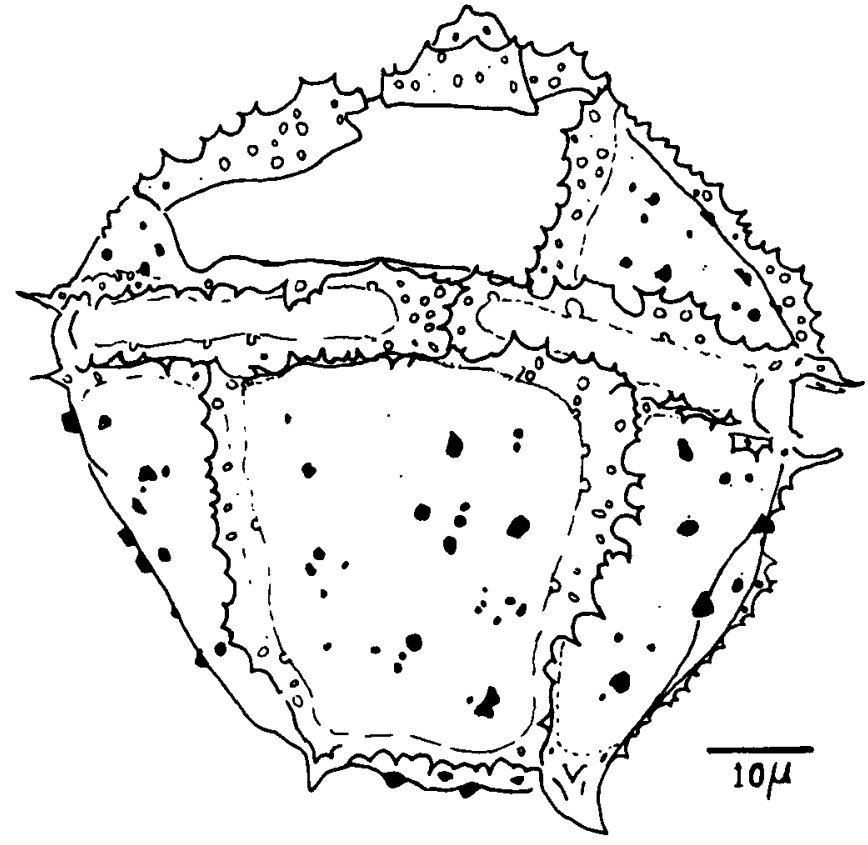

Fig. 3 ionyaulacysta sp. 1.

microperforate crest margins. In addition, Gonyaulacysta sp. 1 has intratabular granules and verrucae. G. pectinigera has a subpentagonal, rather than a subspherical outline. (See also remarks under Gonyaulacysta sp.2 herein).

Occurrence. Brent Group (probably Bathonian) of the northern North Sea.

\section{Gonyaulacysta $\mathrm{sp} .2$}

(Pl.3, figs 1, 2, text-fig.4).

Description. Subpentagonal gonyaulacoid dinocyst of intermediate size (60-80 micrometers). Cysts suturocavate, with wall layers appressed over intratabular areas, separating adjacent to plate boundaries and forming tent-like crests. The crests are proximally peforate to vacuolate and distally denticulate. Many of the larger vacuoles are interrupted by the line of contact between endophragm and periphragm and form broad arches along both flanks of the crest margins. Some vacuoles merge to form heart-shaped arches (see text fig.5). A short apical horn is apparently formed by both wall layers. The tabulation is gonyaulacoid, although the exact formula is uncertain. The archaeopyle is precingular, type $\mathrm{P}$ ( 3 " only).

Remarks. This is a very distinctive species, but only two

\section{Explanation of Plate 2 \\ All $x 800$ approx.}

Figs 1-6,9. Durotrigia aspera sp. nov. 1,2. Holotype. Dorsal view, note the coarse intratabular ornament and the nature of the parasutural features (arrowed). UKCS Well 9/9b-4z, 12314' (slide 1), EF E61/2; 3, 6. Ventral and dorsal foci on specimen with a short apical horn. UKCS Well 9/9b$4 \mathrm{z}, 12331^{\prime}$ (slide 1), EF H60/3; 4, 5. Ventral and dorsal views of specimen with a 2P archaeopyle. UKCS Well 9/8a-7, 12763' (slide 3), EF N60; 9. Ventral view UKCS Well 9/9b-4z, 12314' (slide 1), EF E61/2.

Figs 7, 8. Paragonyaulacysta cf. calloviensis. 7. Focus on ambitus to show the shortened apical hom and ellipsoidal outline; 8 . Lateral focus to show the nature of the parasutural features. UKCS Well 9/8a-7, 12484' (slide 2). EF Q47. 

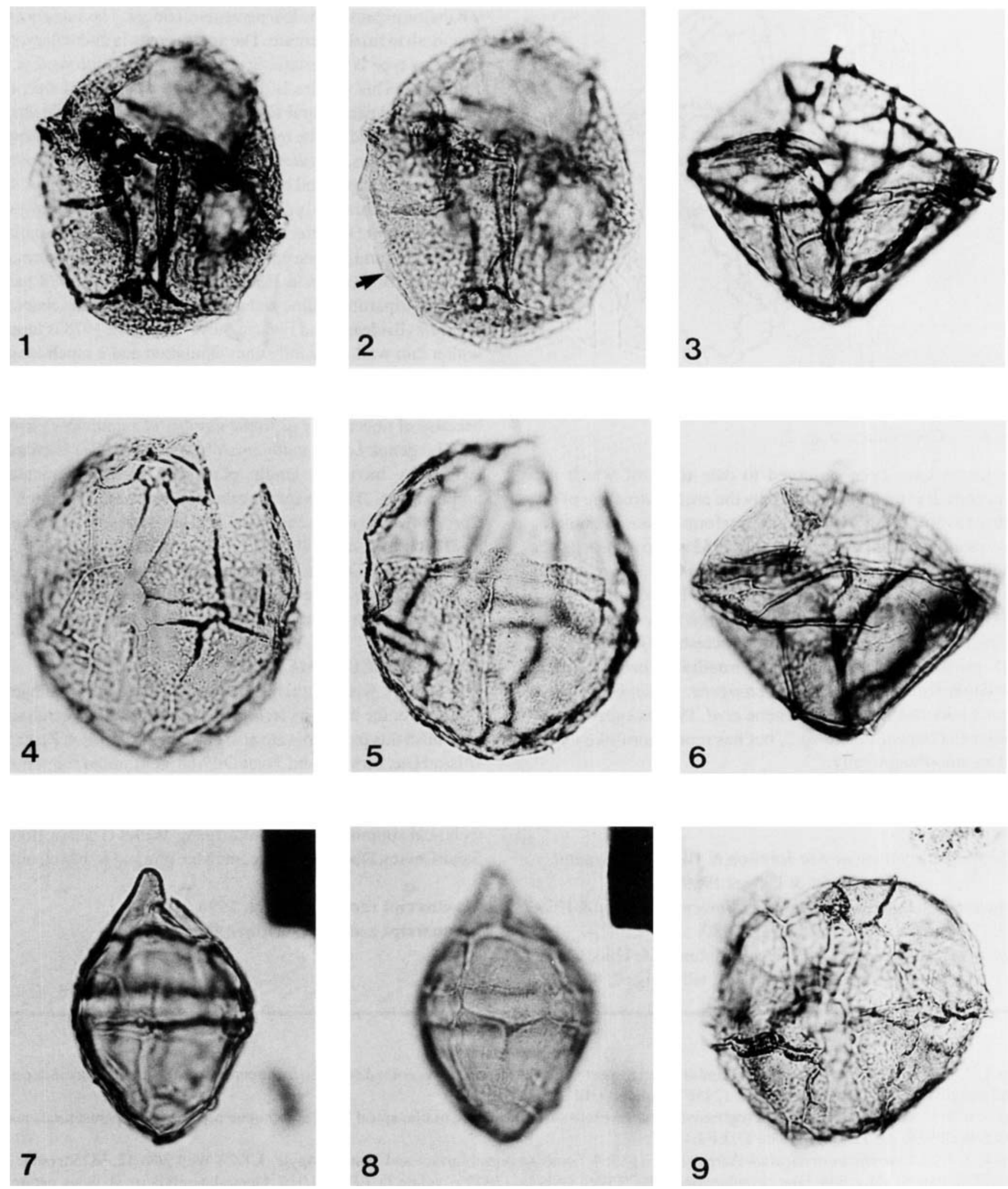


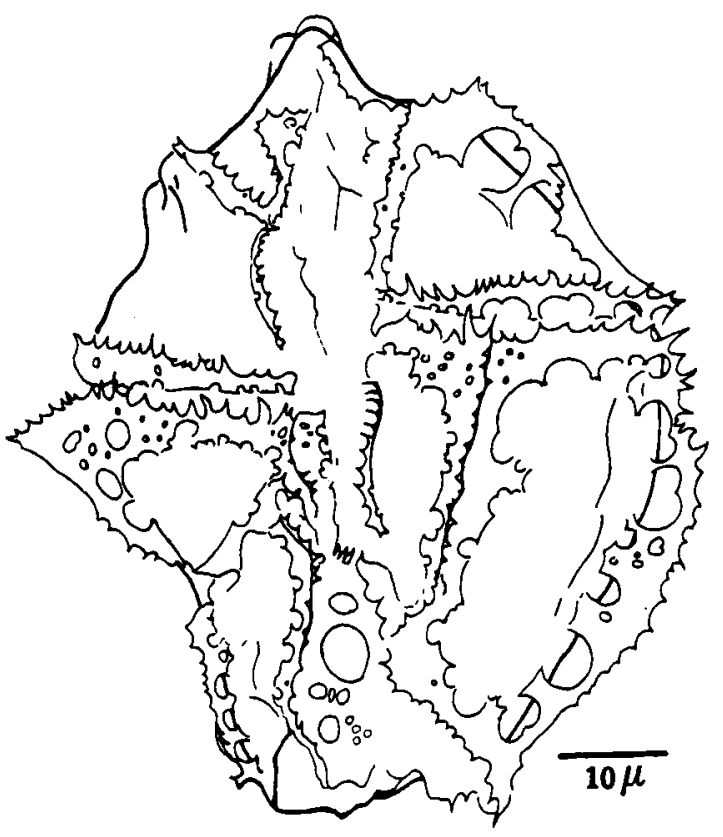

Fig. 4 Gonyaulacysta sp. 2.

specimens have been observed to date (both of which are damaged). It is readily identified by the unique structure of the suturocavate crests which are perforate and vacuolate. Gonyaulacysta centriconnata Riding 1983 is also suturocavate, but the periphragm is entire. Gonyaulacysta $\mathrm{sp.2}$ is related to Gonyaulacysta pectinigera (Gocht 1970) Fensome 1979 and Gonyaulacysta sp. 1 herein. In G. pectinigera the crest margins are microperforate, whilst the perforate crests of Gonyaulacysta sp.1 probably represent an intermediate form between Gonyaulacysta sp.2 and $G$. pectinigera. Rhynchodiniopsis regalis (Gocht 1970) Jan du Chene et al. 1985 is superficially similar to Gonyaulacysta sp. 2 , but has more thorn-like crests and an autophragm only.

Occurrence. Brent Group (probably Bathonian) of the northern North Sea.

Genus Paragonyaulacysta Johnson \& Hills 1973, emend. Dörhöfer \& Davies 1980.

Type species. Paragonyaulacysta calloviensis Johnson \& Hills 1973, emend. Döorhöfer \& Davies 1980.

Paragonyaulacysta? cf. calloviensis Johnson \& Hills 1973, emend. Dörhöfer \& Davies 1980, (Pl.2, figs.7, 8).
Description. Small to intermediate sized proximate dinocyst with a short apical horn and an ellipsoidal outline. Gonyaulacoid tabulation expressed by low parasutural ridges. The autophragm is smooth to finely scabrate. The archaeopyle is intercalary, but the exact type is uncertain. Size range: 45-60 micrometers.

Remarks. This species is distinguished by its small size, the nature of the parasutural features and by the ellipsoidal shape (which is caused by the reduced (or even absent) apical horn). The type species, $P$. calloviensis has a longer horn and stronger sutural crests supported by short gonal spines, which gives this species a more polygonal outline. Paragonyaulacysta retiphragmata Dörhöfer and Davies 1980 has a finely reticulate autophragm and puctate parasutural crests. Paragonyaulacysta capillosa (Brideaux and Fisher) Stover and Evitt 1978 has a strongly tripartite outline and a covering of fine short hairs. $P$. borealis (Brideaux and Fisher) Stover and Evitt 1978 is larger, with a thin wall, very indistinct tabulation and a much longer apical horn.

This taxon is provisionally placed in Paragonyaulacysta because of uncertainty as to the number of intercalary plates.

The genus Lacrymodinium Albert et al. (1987) is characterised by having a single plate mid-dorsal interacalary archaeopyle. The exact number of intercalary plates in Paragonyaulacysta is equivocal, and has been previously cited as 2I (Johnson and Hills 1973, Brideaux and Fisher 1976), 31 (Dorhofer and Davies, 1980) and I-3I (Eaton 1980).

Occurrence. Upper Brent Group and lower Humber Group (Late Bathonian to Early Callovian) of the North Sea.

\section{ACKNOWLEDGEMENTS}

The authors wish to thank the British Petroleum Company Limited for the use of its technical facilities and for permission to publish this paper. We are also grateful to Hamilton Brothers Oil and Gas Limited and Total Oil Marine Limited for permission to publish. Special thanks to the people who have helped in the preparation of this work by their comments, criticism and technical support, they are: Wolfgang Wille, Graham Booth, Steve Davies, Doug Dey, Malcome McClure and Bob McQuillin.

\section{Manuscript received March 1990 \\ Manuscript accepted October 1990}

\section{Explanation of Plate 3}

All x500 approx.

Figs 1, 2. Gonyaulacysta sp.2. Dorsal and ambital foci respectively. Note the large vacuoles developed in the periphragm (bottom centre in 1, righthand margin in 2.) UKCS Well 9/9b-4z, 12456'4" (slide 1), EF H51/2.

Figs 3,6,9 Gonyaulacysia sp. 1. Progressive focus levels to show the nature of trhe apical horn, intratabular ornament and parasutural crests. UKCS Well 9/9b-4z, 12307'6" (slide 1), EF F48/2.

Figs 4, 5, 7, 8. Crusolia perireticulata Aarhus et al. 1989; 4. Focus on dorsal surface and 3 I archaeopyle. UKCS Well 9/9b-12. 3825m (slide 2). EF 252; 5. Lateral view, note faint cingular zone. UKCS Well 9/9b-4z, 12479'6" (slide 1), EF W31/1: 7. Dorso-lateral focus, showing nature of the reticulate periphragm. UKCS Well 9/9b-4z, 12418'6" (slide 1), EF J27/1; 8. Focus on ventral surface. UKCS Well 9/9b-4z, 12418'6" (slide 1), EF R47 

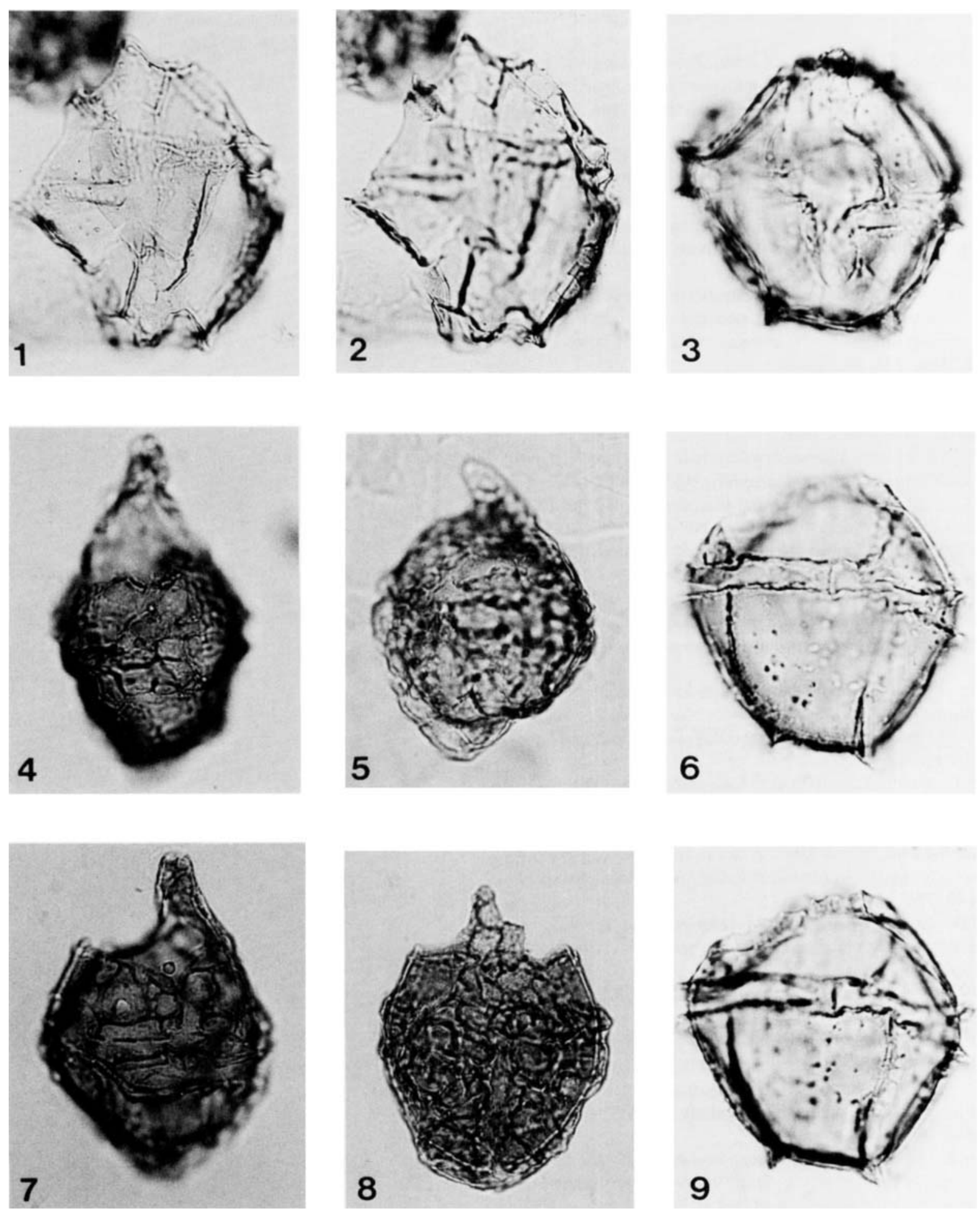


\section{REFERENCES}

Aarhus, N., Birkelund, T. \& Smelror, M. 1989. Biostratigraphy of some Callovian and Oxfordian cores off Vega, Helgeland. Norsk Geol. Tidsskr. 69, 39-56.

Albert, N.R., Evitt, W.R. \& Stein, J.A. 1986. Lacrymodinium, n. gen., a gonyaulacoid dinoflagellate with intercalary archaeopyle from the Jurassic and Early Cretaceous of California and Alaska. Micropalaeontology 32(4), 303-315.

Bailey, D.A. 1987. Durotrigia daveyi gen. et sp.nov., an Early Bajocian dinocyst with a variable precincular archaeopyle. $J$. Micropalaeontol., 6(2), 89-96.

Brideaux, W.W. \& Fisher, M.J. 1976. Upper Jurassic-Lower Cretaceous dinoflagellate assemblages from Arctic Canada. Geol. Surv. Canada, Bulletin 259, 1-53.

Deflandre, G. 1964. Remarques sur la clasification des Dinoflagelles fossiles, a propos d'Evittodinium, nouveau genre cretace de la famille des Deflandreaceae; Comptes rendus de l'Academie des Sciences, Paris, 258, 5027-5030.

Dörhöfer, G. \& Davies, E.H. 1980. Evolution of archaeopyle and tabulation in Rhaetogonyaulacean dinoflagellate cysts. Royal Ont. Mus. Life Sci. Misc. Pubs, 1-91.

Drugg, W.S. 1978. Some Jurassic dinoflagellate cysts from England, France and Germany. Palaeontographica. Abt.B, 168, 61-79.

Eaton, G.L. 1980. Nomenclature and homology in Peridinialean dinoflagellate cysts. Paleontology 23(3), 667-688.

Fensome, R.A. 1979. Dinoflagellate cysts and acritarchs from the Middle and Upper Jurassic of Jameson Land, East Greenland. Grønlands Geologiske Unders $\emptyset$ gelse Bulletin 132, 1-98.

Gocht, H. 1970. Dinoflagellaten-Zystem aus dem Bathonium des Erdofeldes Aldorf (NW-Deutschland). Palaeontographica, Abt.B 129, 125-165.

Jan du Chene, R.E., Fauconnier, D.C. \& Fenton, J.P.G. 1985. Problemes taxonomiques liés a la révision de l'espece "Gonyaulax" cornigera Valensi, 1953, kyste fossile de dinoflagellé. Rev. Micropaléontologie 28(2), 109-124.

Johnson, C.D. \& Hills, L.V. 1973. Microplankton zones of the Savik Formation (Jurassic), Axel Heiberg and Ellesmere Islands, District of Franklin. Bull. Canadian. Pet. Geol. 21, 178-218.

Norris, G. \& Sarjeant, W.A.S. 1965. A descriptive index of genera of fossil Dinophyceae and Acritarcha; N.Z.Geol Surv., Paleontological Bulletin 40, 72p.

Riding, J.B. 1983. Gonyaulacysta centriconnata sp. nov., a dinoflagellate cyst from the Late Callovian and Early Oxfordian of eastern England. Palynology 7, 197-204.

Sarjeant, W.A.S. 1969. Taxonomic changes in Davey, R.J., Downie, C., Sarjeant, W.A.S. and Williams, G.L., Appendix to "Studies on Mesozoic and Cainozoic dinoflatgellate cysts".Bull.Brit.Mus. (Nat. Hist.) Geology, Appendix to Supplement 3, 7-15.

Sarjeant, W.A.S. 1982. The dinoflagellate cysts of the Gonyaulacysta group: a morphological and taxonomic study. A.A.S.P., Contributions Series, 9, 1-80.

Smelror, M. \& Aarhus, N. 1989. Emendation of the dinoflagellate cyst genus Crussolia Wolfard \& Van Erve 1981, and description of $C$. dalei $\mathrm{n}$ sp. from the Callovian of Svalbard. N.Jb. Geol. Paleont.Mh. 1, 37-46.

Stover, L.E. \& Evitt, W.R. 1978. Analyses of pre-Pleistocene organicwalled dinoflagellates. Stanford University Publications, Geological Sciences, 15.
Wolfard, A. \& Van Erve, A.W. 1981. Crussolia deflandrei nov. gen. et nov. sp., a dinoflagellate cyst from the Jurassic (Callovian-Lower Oxfordian) of Montagne Crussol, Rhone Valley, France. Rev. Palaeobot. Palynol., 34, 321-329. 